\title{
THE IMPACT OF GOVERNMENT SUPPORT ON FIRM PERFORMANCE IN VIETNAM: NEW EVIDENCE FROM A DYNAMIC APPROACH
}

\author{
Hoai Thu Thi Nguyen', Huong Vu Van², Francesca Bartolacci, \\ and Tuyen Quang Tran ${ }^{1 *}$ \\ ${ }^{1}$ University of Economics and Business, Vietnam National University, Hanoi, Vietnam \\ ${ }^{2}$ Department of Economics, Academy of Finance, Hanoi, Vietnam \\ ${ }^{3}$ Department of Economics and Law, University of Macerata, Macerata, Italia \\ *Corresponding author: tuyenq@vnu.edu.vn
}

Published online: 21 December 2018

To cite this article: Nguyen, H.T.T., Van, H.V., Bartolacci, F., and Tran, T.Q. (2018). The impact of government support on firm performance in Vietnam: New evidence from a dynamic approach. Asian Academy of Management Journal, 23(2), 101-123. https://doi.org/10.21315/aamj2018.23.2.5

To link to this article: https://doi.org/10.21315/aamj2018.23.2.5

\begin{abstract}
Using a sample of private manufacturing small- and medium-sized enterprises (SMEs) in the period 2007-2015, this paper examines the effect of government support on firms' financial performance in Vietnam. Contrary to many previous studies, the study finds that government assistance affects firms' financial performance after controlling for heterogeneity, unobservable factors, and dynamic endogeneity. The finding supports the viewpoint of institutional theory. The study also reveals that assistance measures, such as tax exemptions, soft loans, and investment incentives to promote financial performance, are vital for the development of Vietnamese private SMEs.
\end{abstract}

Keywords: government support, innovation, firm financial performance, SMEs, Vietnam

\section{INTRODUCTION}

Theoretically, the linkage between government support and firms' financial performance cannot be predicted directly by any single theory. Institutional theory emphasises the effectiveness of government subsidies as a catalyst for external investments, and Takalo and Tanayama (2010) show that firms receiving

(C) Asian Academy of Management and Penerbit Universiti Sains Malaysia, 2018. This work is licensed under the terms of the Creative Commons Attribution (CC BY) (http://creativecommons. org/licenses/by/4.0/). 
government support may give a positive signal to market-based financiers. As a result, they may receive higher external investment than their counterparts without such support. Also, government support can result in additional funding sources to provide firms with more resources where sources are limited. Furthermore, private enterprises may overcome institutional and other barriers on an uneven playing field through the efficiency of government support (Hansen, Rand, \& Tarp, 2009). Consequently, firms with government support will increase research and development (R\&D) input and thus improve their performance (Wu, 2017).

On the other hand, rent-seeking viewpoints indicate that government subsidies will not necessarily be distributed effectively because the granting of subsidies is not based on a firm's promising prospects or social contribution. As a result, subsidies based on social networks or political connections are not beneficial to company performance. Such biases in government support tend to increase distortion in the efficient allocation of resources among companies, and hence may result in slow profit growth or the reduction of returns on asset and financial performance (Zhang, Li, Zhou, \& Zhou, 2014).

In light of these theoretical perspectives, many empirical studies have been conducted in various countries. However, few studies have focused on the role of government support on the development of small- and medium-sized enterprises (SMEs) in developing countries. In addition, the findings are inconclusive, making it hard to draw general inferences. For example, Fajnzylber, Maloney, and MontesRojas (2009) found that government support did not significantly affect profitability in Mexico. However, Hansen et al. (2009) show that government assistance helps firms improve their performance and survival.

The current study differs significantly from previous ones in three ways. First, whereas most studies focus on analysis of the US and other developed countries, this study provides the first evidence of the role of government support on firms' financial performance in Vietnam. Furthermore, different types of government support can have varying effects on firms' financial performance. In our study, we go beyond the extant literature by examining the effect of various types of government support on firms' financial performance. Finally, in methodology, the majority of previous studies (e.g., Zhang et al., 2014) often consider the linkage between government support and firms' financial performance using ordinary least squares (OLS) for pooled or panel data regression. However, such approaches cannot overcome several empirical challenges, such as the endogeneity of explanatory variables. More importantly, the presence of potential dynamic endogeneity can be understood as a firm's past financial performance affecting 
current performance. Following Wintoki, Linck, and Netter (2012), we overcome these problems by using a two-step system dynamic panel, the generalised method of moments (GMM) model.

This paper is structured as follows. The next section provides the background and literature for the research. The following section discusses data sources and analysis framework. Empirical results are presented in the following section. The final section offers a summary and conclusions.

\section{THE BACKGROUND OF GOVERNMENT SUPPORT AND ITS ROLE IN SME PERFORMANCE}

Recognising that SMEs, especially private firms, are the critical engine for Vietnamese economic growth, the government of Vietnam has set up supporting measures and issued various decrees. Table 1 lists a series of policy measures, including financial access, human resource development, technical support, and trade and export promotion for SMEs in Vietnam.

Although these policies cover all the various aspects of support for SMEs, difficulties in their implementation still exist because of unclear and unrealistic requirements (Le, 2010). For example, a recent decree (56/2009/ND-CP) lists types of support that SMEs can receive from the government. In practice, however, the guidelines are not clear or lack sufficient detail (Anh, Mai, Nhat, \& Chuc, 2011). Consequently, it takes much time and effort for SMEs to receive the support offered. In addition, although the leading role of the state sector has been removed, discrimination against non-state SMEs still exists. In addition, corruption remains widespread (Nguyen \& Van Dijk, 2012; Vu, Tran, Nguyen, \& Lim, 2018). According to the Central Institute for Economic Management (CIEM, 2010), Vietnamese SMEs are likely to make informal payments for receiving support from the government. Hence, when assessing financial performance, it is not clear whether the benefits of government support outweigh the costs or vice versa. The context motivates us to evaluate whether government assistance is beneficial to the financial performance of firms and if so, how?

The literature has documented many studies considering the linkage between government support and firm performance (Cowling, 2010; Lerner, 1999; Rotger, Gørtz, \& Storey, 2012). However, the linkage between government assistance and the performance of SMEs has attracted little empirical attention. On the one hand, some studies show that government support has little effect on SME performance. 
For example, using a panel dataset on SMEs in the Japanese manufacturing industry, Honjo and Harada (2006) reveal that government initiatives played an inconsequential role in SME sales, employment, and revenues.

On the other hand, Doh and Kim (2014) explore the effects of governmental policies on SME innovation in regional strategic industries in South Korea using technological development assistance funds as a proxy. Results from empirical models indicate that a positive relationship exists between technological support and innovation performance. The study suggests that governmental financial aid is important for SME innovation.

Table 1

Overview of government support for SMEs through various period of time

\section{1}

Decision No. 193/2001/QD/-TTg, issued on 20 December 2001 by the Prime Minister, on the promoting for the establishment and operation as well as credit guarantees for SMEs.

\section{2}

Circular No. 86/2002/TT-BTC, issued on 27 September 2002 by the Ministry of Finance, on guiding the utilisation of the budget in support of trade and export promotion activities.

\section{3}

Decision No. 12/2003/QD-TTg, issued on 17 January 2003 by the Prime Minister, on the functions, responsibility and membership of the Small and Medium Enterprises Development Promotion Council.

Decision No. 104/203/QD-BTM, issued on 24 January 2003 by the Ministry of Trade, on promulgating the regulations for the formulation and management of national key trade promotion programmes.

Decision No. 185/QD-BKH, issued on 24 March 2003 by the Chairman of the Small and Medium Enterprises Development Promotion Council, on the promulgation of an operational statute for the Small and Medium Enterprises Development Promotion Council.

Decision No. 290/QD-BKH, issued on 29 July 2003 by the Ministry of Planning and Investment, on the establishment of technical assistance centres for SMEs in Hanoi, Da Nang, and Ho Chi Minh City.

Decision No. 504/QD-BKH, issued on 29 July 2003 by the Ministry of Planning and Investment, on the functions, responsibility, and organisational structure of the Agency for the Development of Small and Medium Enterprises.

Directive No. 27/2003/CT-TTg, issued on 11 December 2003 by the Prime Minister, on continuing to step up the implementation of the enterprise law and encouraging SME development.

\section{4}

Decision No. 115/2004/QD-TTg, issued on 25 June 2004 by the Prime Minister, on revision and amendment to the statute for the establishment, organisation, and operation of the credit guarantee fund for SMEs promulgated in decision No. 193/2001/QD-TTg, issued on 20 December 2001 by the Prime Minister. 
Table 1 (continued)

\section{4}

Decision No. 143/2004/QD-TTg, issued on 10 August by the Prime Minister, on approval for the Human Resources Development Assistance Program for SMEs.

Circular No. 93/2004/TT-BTC, issued on 29 September 2004 by the Ministry of Finance.

Circular on regulations for the Credit Guarantee Fund for SMEs.

Guidelines of the Ministry of Planning and Investment for implementation of the SME Human Resource Development Program, 24 November 2004.

\section{5}

Resolution No. 144/2005/TB-BKH, issued on 07 October 2005 by the SME Council, on the SME Development Plan 2006-2010.

Directive No. 40/2005/CT-TTg, issued on 16 December 2005 by the Prime Minister, on the enhancement of support for the development of SMEs.

\section{6}

Circular No. 01/2006, issued on 20 February 2006 by the State Bank of Vietnam, on the contribution of capital to guarantee credit for SMEs.

Decision No. 236/2006/QD-TTg, issued on 23 October 2006 by the Prime Minister, on approval of the SME Development Plan 2006-2010.

Decision No. 48/2006/QD-BTC, issued on 14 September 2006 by the Ministry of Finance, on the new accounting system for SMEs.

\section{7}

Directive No. 22/2007/CT-TTg, issued on 26 October 2007 by the Prime Minister, on the development of non-state enterprises.

\section{9}

Decree No. 90/2001/ND-CP on support for the development of SMEs was replaced by Decree No. $56 / 2009 / \mathrm{NĐ}-\mathrm{CP}$, issued on 30 June 2009 by the government.

\section{2}

Decision No. 1231/2012/QD-TTg, issued on 07 September 2012 by the Prime Minister, concerning approval of the development plan for SMEs 2011-2015.

\section{6}

Decision No. 89/2015/QH13, issued by the Parliament, showing strong commitment and willingness on the part of the government to support and develop SMEs.

Source: Authors' synthesis from documents of the Agency for Small and Medium Enterprise Development, Ministry of Planning and Investment

The objective of another study was to analyse the impact of public support on Spanish SME performance, considering technological and economic results. Empirical evidence corroborates the direct, positive influence of support on the technological assets of participants. From the economic performance point of view, economic indicators are positively influenced by the improvement in technological background (Barajas, Huergo, \& Moreno, 2017). 
In some cases, mixed results are found in each study. For example, Morris and Stevens (2010) evaluated the impact of a New Zealand government support programme on participating firms, using a new firm-level panel dataset for 2000 to 2006. They found that the programme achieved significant positive results for sales, although the effect on added value and productivity was less conclusive. Maggioni, Sorrentino, and Williams (1999) examined how the most important government programme to encourage entrepreneurship in Italy affected several aspects of the early performance of new firms. Results showed that the public programme produced mixed effects. Government aid allowed firms to acquire a higher level of technology, but government funding gave rise to entrepreneurial start-ups, which are not always fully efficient.

Few contributions deal with the influence of government support on SME performance in developing countries and these still reach different conclusions. Fajnzylber et al. (2009) consider the role of diverse types of government support on firm performance in Mexico. Their research found that the significant intracountry differences in firm productivity observed in developing economies were due in part to market and government failures that limit the ability of micro-firms to reach their optimal sizes. However, in another article, Wei and Liu (2015) examine the effect of government support in the Chinese context and consider a different type of effect on the innovation performance of firms. They divided government support into what they term "vertical and horizontal support," and adopted an empirical research approach in their study. In their results, the authors highlighted that vertical support, in the form of direct R\&D subsidies, horizontal support, and regional innovation policy, have a positive effect on the innovation performance of firms.

In Vietnam, a growing literature examines the role of government support in firm performance. Several studies show that government support is an effective tool to improve firm growth and survival (e.g., Hansen et al., 2009). Other research reveals that the effect of government support on firm performance is negligible or insignificant (Vu, Holmes, Tran, \& Lim, 2016). However, the evidence about the linkage between government support and firms' financial performance is little known, especially for private SMEs. In addition, there is limited understanding of the effect of government support on firms' financial performance. Investigating subsidies as a whole instead of types of subsidy may obscure the real effect of government support on firms' performance. More precisely, few studies have examined the relationship between government support and SMEs' financial performance with reference to developing countries, particularly Vietnam, considering the effect of government assistance and types of support on SMEs' financial performance. Hence, the contribution of this study will be to fill the 
gap in the literature by using a dynamic GMM approach to consider the role of government support on firms' financial performance in the Vietnamese domestic SME manufacturing context.

\section{DATA AND ECONOMETRIC MODELS}

\section{Data}

This study utilises the Small and Medium Enterprise (SME) Survey - Enterprise Development in Vietnam (Copenhagen Centre of Development Research University of Copenhagen). The surveys were conducted in collaboration with two central Vietnamese partners, i.e., CIEM and the Institute of Labour, Science and Social Affairs (ILSSA). ${ }^{1}$

The surveys focused on manufacturing SMEs in Vietnam and were conducted every two years, in 2005, 2007, 2009, 2011, 2013, and 2015. The surveys covered 10 provinces (Ho Chi Minh City, Hanoi, Hai Phong, Long An, Ha Tay, Quang Nam, Phu Tho, Nghe An, Khanh Hoa, and Lam Dong) and 3 regions (South, Central, and North). However, this study uses an unbalanced panel dataset in 19 manufacturing sectors from 2007 to 2015 because information concerning types of government support is not available for 2005.

To provide a comprehensive analysis of different types of SMEs, the surveys followed a stratified random sampling method according to ownership structures. The surveys provide a wide range of indicators of firm characteristics, including ownership, industry, enterprise history, government support, types of government support, financial performance, and other information. This dataset made it possible to analyse the impact of government support on the financial performance of Vietnamese SMEs. A common problem with time-variant data is that they are often expressed in current prices. Therefore, our data on current variables are deflated to 1994 prices using GDP deflators to avoid biases that might arise because of inflation. A statistical description of the main variables in our regression estimations is given in Table $2 .^{2}$

\section{Econometric models}

To quantify the role of government support in firms' financial performance, we apply a dynamic model approach. Such approaches have become increasingly important in recent years to deal with the dynamic nature of economic processes (Flannery \& Hankins, 2013). It is this dynamic nature which renders problematic 
Hoai Thu Thi Nguyen et al.

Table 2

Summary statistics for the main variables in the model

\begin{tabular}{|c|c|c|c|c|c|c|c|c|c|c|}
\hline \multirow{2}{*}{ Variable } & \multicolumn{2}{|c|}{2007} & \multicolumn{2}{|c|}{2009} & \multicolumn{2}{|c|}{2011} & \multicolumn{2}{|c|}{2013} & \multicolumn{2}{|c|}{2015} \\
\hline & Mean & SD & Mean & SD & Mean & SD & Mean & $\mathrm{SD}$ & Mean & SD \\
\hline ROA & 0.22 & 1.73 & 0.266 & 0.58 & 0.241 & 0.65 & 0.307 & 1.72 & 0.35 & 0.94 \\
\hline ROE & 0.21 & 2.27 & 0.37 & 3.32 & 0.34 & 3.08 & 0.31 & 1.88 & 0.42 & 1.49 \\
\hline Government assistance & 0.23 & 0.42 & 0.32 & 0.46 & 0.143 & 0.35 & 0.115 & 0.31 & 0.084 & 0.27 \\
\hline Financial support & 0.196 & 0.39 & 0.292 & 0.45 & 0.101 & 0.302 & 0.097 & 0.29 & 0.052 & 0.22 \\
\hline Technical support & 0.04 & 0.198 & 0.027 & 0.164 & 0.028 & 0.167 & 0.022 & 0.14 & 0.006 & 0.08 \\
\hline Innovation & 0.48 & 0.49 & 0.45 & 0.49 & 0.44 & 0.49 & 0.197 & 0.39 & 0.33 & 0.47 \\
\hline Bribes & 0.267 & 0.44 & 0.342 & 0.47 & 0.38 & 0.486 & 0.445 & 0.49 & 0.42 & 0.495 \\
\hline Export & 0.058 & 0.23 & 0.057 & 0.23 & 0.06 & 0.23 & 0.062 & 0.24 & 0.07 & 0.255 \\
\hline Firm size in log & 2.08 & 1.17 & 2.06 & 1.16 & 1.81 & 1.15 & 1.73 & 1.15 & 1.78 & 1.15 \\
\hline Firm age in log & 2.35 & 0.71 & 2.42 & 0.73 & 2.38 & 0.67 & 2.55 & 0.63 & 2.62 & 0.63 \\
\hline Leverage & 0.11 & 0.273 & 0.10 & 0.23 & 0.079 & 0.19 & 0.07 & 0.24 & 0.087 & 0.235 \\
\hline Observations & \multicolumn{2}{|c|}{2518} & \multicolumn{2}{|c|}{2527} & \multicolumn{2}{|c|}{2417} & \multicolumn{2}{|c|}{2424} & \multicolumn{2}{|c|}{2486} \\
\hline
\end{tabular}

Source: Authors' calculation from the SME survey, 2007-2015

Note: $\mathrm{ROA}=$ return on assets; $\mathrm{ROE}=$ return on equity

traditional estimation techniques, including OLS and fixed-effects (FE) (Flannery \& Hankins, 2013; Wintoki et al., 2012). As shown in many previous studies (e.g., Wintoki et al., 2012), empirical models using firms' financial performance as a dependent variable must be examined in a dynamic framework in which lagged dependent variable(s) are considered as explanatory variable(s).

Technically, the inclusion of lagged dependent variable(s) as independent variables of the empirical models allows researchers to control for unobserved historical factors which have potential influence on current firm performance, in this way reducing omitted variable bias (Wooldridge, 2009). Thus, guided by previous studies (Wintoki et al., 2012), the empirical approach taken in this study is specified below:

$$
\begin{aligned}
Y_{i t}= & \alpha_{0}+\sum_{s=1}^{k} a_{s} Y_{i t-s}+\delta_{m} \text { Government support } t_{i t}+\beta_{k} Z_{k, i t} \\
& + \text { year dummies }+ \text { industry dummies }+\mu_{i}+\vartheta_{i t}
\end{aligned}
$$

where $Y_{i t}$ is the financial performance (as measured by ROA or ROE) of firm $i$ in year $t ; \alpha_{1}$ is the estimated coefficient on a one-year lagged dependent variable; government support is widely defined as a dummy variable to reduce measurement errors. This is the main interest variable in the model. In this study, we measure 
government support as a set of variables. First, it is measured as a dummy, based on the question whether firms have received assistance. In addition, the type of government support is measured on the basis of the question about what assistance firms have received.

$Z$ is a vector of firm-level explanatory variables used in the model as guided by previous studies (e.g., firm size, firm age, innovation, and leverage). We also control for potential influences arising from differences across industries, using dummy variables for industry classification. $\mu_{i}$ represents time-invariant unobserved firm characteristics; $\omega_{t}$ denotes time-specific effects which are time-variant and common to all firms. These time-specific effects are captured by year dummy variables; $\varepsilon_{i t}$ is the classical error term.

The information from the past can be captured sufficiently by two lags of the dependent variable (e.g., Adams \& Ferreira, 2009). However, when we ran a specification in which current financial performance is a dependent variable regressed on two lags of past performance and using other covariates as in Equation 1, an insignificant effect of $Y_{i t-2}$ on current firm financial performance was found. This result implies that a one-year lagged dependent variable as an explanatory variable in a first-order autoregressive [AR(1)] structure is enough to control for potential dynamic endogeneity. The specification with AR(1) structure is consistent with the arguments of previous studies (Zhou, Faff, \& Alpert, 2014), which show that an AR(1) structure appears to be unavoidable when almost all panel datasets used in corporate finance research are short. Hence, the panel specification model (1) with an $\mathrm{AR}(1)$ structure can be written as follow:

$$
\begin{aligned}
Y_{i t}= & \alpha_{0}+\alpha_{1} Y_{i, t-1}+\delta_{m} \text { Government support } t_{i t}+\beta_{k} Z_{k, i t} \\
& + \text { year dummies }+ \text { industry dummies }+\mu_{i}+\vartheta_{i t}
\end{aligned}
$$

For the estimation approach, the pooled OLS and the OLS with FE methods will provide inconsistent estimations in the presence of the AR(1) structure and endogenous explanatory variables (Flannery \& Hankins, 2013). Some studies use a traditional instrumental variable (IV) approach. However, findings from a set of external instrumental variables seem infeasible when almost no independent variables are considered to be exogenous. Consequently, we use the system generalised method of moments (System GMM) estimator proposed by Blundell and Bond (1998) to correct for this inconsistency and these challenges. This estimator is superior to OLS or fixed effects in controlling for time-invariant unobserved heterogeneity across firms, simultaneity, and dynamic endogeneity (Blundell \& Bond, 1998; Wintoki et al., 2012). 


\section{EMPIRICAL RESULTS AND DISCUSSION}

This section describes the results of the empirical analysis. Table 3 column 1 shows the effect of government support on firms' financial performance when using the OLS approach for pooled data, while Table 3 column 2 shows estimated results after controlling for unobservable time-invariant factors. Table 3 column 3 provides dynamic two-step GMM regressions with basic estimation, while columns 4 to 6 report the results from the estimation of extended specifications.

Table 3

The impact of government support on firms' financial performance

\begin{tabular}{|c|c|c|c|c|c|c|}
\hline \multirow{3}{*}{ Variables } & ROA & ROA & ROA & ROA & ROA & ROA \\
\hline & Pooled & FE & Dynamic GMM & Pooled & FE & Dynamic GMM \\
\hline & (1) & (2) & (3) & (4) & (5) & (6) \\
\hline lagROA & & & $\begin{array}{l}0.1541^{* *} \\
(0.078)\end{array}$ & $\begin{array}{l}0.3199^{* * *} \\
(0.083)\end{array}$ & $\begin{array}{c}-0.2378^{* *} \\
(0.117)\end{array}$ & $\begin{array}{l}0.1449^{* *} \\
(0.072)\end{array}$ \\
\hline Government support & $\begin{array}{c}-0.0069 \\
(0.020)\end{array}$ & $\begin{array}{c}0.0071 \\
(0.030)\end{array}$ & $\begin{array}{l}0.0393^{* *} \\
(0.018)\end{array}$ & $\begin{array}{c}-0.0100 \\
(0.023)\end{array}$ & $\begin{array}{c}-0.0110 \\
(0.042)\end{array}$ & $\begin{array}{l}0.0360^{*} \\
(0.022)\end{array}$ \\
\hline Firm size in log & $\begin{array}{l}-0.0386^{* * *} \\
(0.014)\end{array}$ & $\begin{array}{c}-0.0356 \\
(0.025)\end{array}$ & $\begin{array}{c}0.0093 \\
(0.021)\end{array}$ & $\begin{array}{c}-0.0273 \\
(0.020)\end{array}$ & $\begin{array}{c}-0.0460 \\
(0.081)\end{array}$ & $\begin{array}{c}0.0076 \\
(0.019)\end{array}$ \\
\hline Firm age in log & $\begin{array}{c}-0.0575^{* * *} \\
(0.019)\end{array}$ & $\begin{array}{c}-0.0094 \\
(0.032)\end{array}$ & $\begin{array}{c}-0.0260 \\
(0.033)\end{array}$ & $\begin{array}{c}-0.0106 \\
(0.017)\end{array}$ & $\begin{array}{c}-0.0106 \\
(0.032)\end{array}$ & $\begin{array}{c}-0.0319 \\
(0.030)\end{array}$ \\
\hline Innovation & & & & $\begin{array}{c}-0.0186 \\
(0.017)\end{array}$ & $\begin{array}{c}0.0226 \\
(0.039)\end{array}$ & $\begin{array}{c}-0.0100 \\
(0.016)\end{array}$ \\
\hline Bribes & & & & $\begin{array}{c}-0.0593^{* * * *} \\
(0.018)\end{array}$ & $\begin{array}{c}-0.0606 \\
(0.048)\end{array}$ & $\begin{array}{r}-0.0219 \\
(0.014)\end{array}$ \\
\hline Export & & & & $\begin{array}{l}0.1035^{* *} \\
(0.043)\end{array}$ & $\begin{array}{c}-0.0667 \\
(0.078)\end{array}$ & $\begin{array}{c}0.0590 \\
(0.065)\end{array}$ \\
\hline Leverage & & & & $\begin{array}{l}0.1633^{* *} \\
(0.083)\end{array}$ & $\begin{array}{c}0.0268 \\
(0.063)\end{array}$ & $\begin{array}{c}0.0543 \\
(0.065)\end{array}$ \\
\hline Tobacco sector & $\begin{array}{c}-0.2869^{* * *} \\
(0.042)\end{array}$ & $\begin{array}{c}-1.9228^{* * *} \\
(0.438)\end{array}$ & $\begin{array}{r}-0.5671 \\
(0.392)\end{array}$ & $\begin{array}{c}-0.2346^{* * *} \\
(0.048)\end{array}$ & $\begin{array}{c}-4.8737 \\
(4.634)\end{array}$ & $\begin{array}{c}-0.5766^{*} \\
(0.343)\end{array}$ \\
\hline Textiles sector & $\begin{array}{l}-0.1932^{* * *} \\
(0.041)\end{array}$ & $\begin{array}{c}-1.6025^{* * *} \\
(0.241)\end{array}$ & $\begin{array}{c}-0.3966^{* *} \\
(0.180)\end{array}$ & $\begin{array}{c}-0.1083^{* *} \\
(0.055)\end{array}$ & $\begin{array}{c}-4.0579 \\
(4.043)\end{array}$ & $\begin{array}{c}-0.3794^{* *} \\
(0.148)\end{array}$ \\
\hline Apparel sector & $\begin{array}{c}-0.0622 \\
(0.050)\end{array}$ & $\begin{array}{c}-1.7300^{* * *} \\
(0.250)\end{array}$ & $\begin{array}{c}-0.4956^{* * *} \\
(0.183)\end{array}$ & $\begin{array}{c}-0.0655 \\
(0.047)\end{array}$ & $\begin{array}{c}-4.3637 \\
(4.049)\end{array}$ & $\begin{array}{l}-0.4900^{* * *} \\
(0.159)\end{array}$ \\
\hline Leather sector & $\begin{array}{l}-0.1386^{* * *} \\
(0.049)\end{array}$ & $\begin{array}{c}-1.8842^{* * *} \\
(0.239)\end{array}$ & $\begin{array}{c}-0.3414^{*} \\
(0.180)\end{array}$ & $\begin{array}{c}-0.1470^{* * *} \\
(0.045)\end{array}$ & $\begin{array}{c}-4.2218 \\
(4.044)\end{array}$ & $\begin{array}{c}-0.3512^{*} \\
(0.180)\end{array}$ \\
\hline Wood sector & $\begin{array}{l}-0.1612^{* * *} \\
(0.032)\end{array}$ & $\begin{array}{l}-1.8002^{* * *} \\
(0.193)\end{array}$ & $\begin{array}{l}-0.3577^{* * *} \\
(0.127)\end{array}$ & $\begin{array}{l}-0.1294^{* * *} \\
(0.037)\end{array}$ & $\begin{array}{c}-4.1454 \\
(3.978)\end{array}$ & $\begin{array}{l}-0.3619^{* * *} \\
(0.108)\end{array}$ \\
\hline
\end{tabular}


Table 3 (continued)

\begin{tabular}{|c|c|c|c|c|c|c|}
\hline \multirow{3}{*}{ Variables } & ROA & ROA & ROA & ROA & ROA & ROA \\
\hline & Pooled & $\mathrm{FE}$ & Dynamic GMM & Pooled & $\mathrm{FE}$ & Dynamic GMM \\
\hline & (1) & (2) & (3) & (4) & (5) & (6) \\
\hline Paper sector & $\begin{array}{l}-0.1764^{* * *} \\
(0.033)\end{array}$ & $\begin{array}{l}-1.4617^{* * *} \\
(0.199)\end{array}$ & $\begin{array}{l}-0.5449^{* *} \\
(0.228)\end{array}$ & $\begin{array}{l}-0.1298^{* * *} \\
(0.033)\end{array}$ & $\begin{array}{l}-3.1901 \\
(3.054)\end{array}$ & $\begin{array}{l}-0.5147^{* *} \\
(0.222)\end{array}$ \\
\hline $\begin{array}{l}\text { Publishing and printing } \\
\text { sector }\end{array}$ & $\begin{array}{l}-0.1455^{* * *} \\
(0.046)\end{array}$ & $\begin{array}{l}-1.6363^{* * *} \\
(0.253)\end{array}$ & $\begin{array}{c}-0.3952^{*} \\
(0.208)\end{array}$ & $\begin{array}{l}-0.1236^{* * *} \\
(0.054)\end{array}$ & $\begin{array}{l}-4.0945 \\
(3.921)\end{array}$ & $\begin{array}{l}-0.4513^{* *} \\
(0.223)\end{array}$ \\
\hline $\begin{array}{l}\text { Refined petroleum } \\
\text { sector }\end{array}$ & $\begin{array}{l}-0.2538^{* * *} \\
(0.042)\end{array}$ & $\begin{array}{l}-1.6566^{* * *} \\
(0.415)\end{array}$ & $\begin{array}{c}-0.3372^{*} \\
(0.178)\end{array}$ & $\begin{array}{l}-0.1868^{* * *} \\
(0.057)\end{array}$ & $\begin{array}{c}0.0806 \\
(0.055)\end{array}$ & $\begin{array}{l}-0.3111^{*} \\
(0.161)\end{array}$ \\
\hline $\begin{array}{l}\text { Chemical products } \\
\text { sector }\end{array}$ & $\begin{array}{l}-0.2057^{* * *} \\
(0.041)\end{array}$ & $\begin{array}{l}-1.8033^{* * *} \\
(0.246)\end{array}$ & $\begin{array}{c}-0.4449 \\
(0.271)\end{array}$ & $\begin{array}{l}-0.1170^{* *} \\
(0.050)\end{array}$ & $\begin{array}{c}-3.9307 \\
(3.880)\end{array}$ & $\begin{array}{c}-0.4395^{*} \\
(0.240)\end{array}$ \\
\hline Rubber sector & $\begin{array}{l}-0.1551^{* * *} \\
(0.042)\end{array}$ & $\begin{array}{l}-1.8992^{* * *} \\
(0.199)\end{array}$ & $\begin{array}{l}-0.5570^{* * *} \\
(0.191)\end{array}$ & $\begin{array}{c}-0.0849 \\
(0.052)\end{array}$ & $\begin{array}{l}-4.2615 \\
(4.054)\end{array}$ & $\begin{array}{l}-0.5382^{* * *} \\
(0.175)\end{array}$ \\
\hline $\begin{array}{l}\text { Non-metallic mineral } \\
\text { products sector }\end{array}$ & $\begin{array}{l}-0.1447^{* * *} \\
(0.035)\end{array}$ & $\begin{array}{l}-2.0073^{* * *} \\
(0.225)\end{array}$ & $\begin{array}{c}-0.4248^{*} \\
(0.170)\end{array}$ & $\begin{array}{l}-0.0805^{* *} \\
(0.036)\end{array}$ & $\begin{array}{l}-4.6997 \\
(4.587)\end{array}$ & $\begin{array}{l}-0.4424^{* * *} \\
(0.149)\end{array}$ \\
\hline Basic metals sector & $\begin{array}{c}-0.0932 \\
(0.105)\end{array}$ & $\begin{array}{l}-2.4409^{* * *} \\
(0.235)\end{array}$ & $\begin{array}{l}-0.7329^{* *} \\
(0.329)\end{array}$ & $\begin{array}{c}0.0441 \\
(0.161)\end{array}$ & $\begin{array}{c}-5.5722 \\
(5.247)\end{array}$ & $\begin{array}{l}-0.6767^{* *} \\
(0.317)\end{array}$ \\
\hline $\begin{array}{l}\text { Manufactured metal } \\
\text { products sector }\end{array}$ & $\begin{array}{l}-0.1373^{* * *} \\
(0.036)\end{array}$ & $\begin{array}{l}-2.4779^{* * *} \\
(0.197)\end{array}$ & $\begin{array}{l}-0.6075^{* *} \\
(0.280)\end{array}$ & $\begin{array}{l}-0.0910^{* * *} \\
(0.039)\end{array}$ & $\begin{array}{c}-5.5478 \\
(5.306)\end{array}$ & $\begin{array}{l}-0.5443^{* *} \\
(0.251)\end{array}$ \\
\hline $\begin{array}{l}\text { Electronic machinery, } \\
\text { computers, radio sector }\end{array}$ & $\begin{array}{l}-0.1599^{* * *} \\
(0.040)\end{array}$ & $\begin{array}{l}-2.3480^{* * *} \\
(0.228)\end{array}$ & $\begin{array}{l}-0.6179^{* *} \\
(0.274)\end{array}$ & $\begin{array}{r}-0.0702 \\
(0.047)\end{array}$ & $\begin{array}{c}-5.3180 \\
(5.004)\end{array}$ & $\begin{array}{l}-0.6699^{* *} \\
(0.303)\end{array}$ \\
\hline Motor vehicles sector & $\begin{array}{l}-0.2290^{* * *} \\
(0.045)\end{array}$ & $\begin{array}{l}-2.4262^{* * *} \\
(0.278)\end{array}$ & $\begin{array}{c}-0.5500 \\
(0.359)\end{array}$ & $\begin{array}{l}-0.1435^{* * *} \\
(0.050)\end{array}$ & $\begin{array}{c}-4.9746 \\
(4.682)\end{array}$ & $\begin{array}{r}-0.4145 \\
(0.267)\end{array}$ \\
\hline $\begin{array}{l}\text { Other transport } \\
\text { equipment sector }\end{array}$ & $\begin{array}{l}-0.1718^{* *} \\
(0.069)\end{array}$ & $\begin{array}{l}-2.4131^{* * *} \\
(0.329)\end{array}$ & $\begin{array}{l}-0.4621^{* *} \\
(0.183)\end{array}$ & $\begin{array}{l}-0.2107^{* *} \\
(0.090)\end{array}$ & $\begin{array}{c}-5.5234 \\
(5.050)\end{array}$ & $\begin{array}{l}-0.4966^{* *} \\
(0.226)\end{array}$ \\
\hline $\begin{array}{l}\text { Furniture, jewellery, } \\
\text { music equipment sector }\end{array}$ & $\begin{array}{l}-0.1790^{* * *} \\
(0.036)\end{array}$ & $\begin{array}{l}-1.8185^{* * *} \\
(0.194)\end{array}$ & $\begin{array}{l}-0.3932^{* * *} \\
(0.133)\end{array}$ & $\begin{array}{l}-0.1235^{* * *} \\
(0.039)\end{array}$ & $\begin{array}{l}-4.1706 \\
(4.061)\end{array}$ & $\begin{array}{l}-0.3907^{* * *} \\
(0.120)\end{array}$ \\
\hline Recycling sector & $\begin{array}{l}-0.2286^{* * *} \\
(0.076)\end{array}$ & $\begin{array}{l}-2.4582^{* * *} \\
(0.342)\end{array}$ & $\begin{array}{l}-0.6768^{* *} \\
(0.282)\end{array}$ & $\begin{array}{r}-0.0881 \\
(0.113)\end{array}$ & $\begin{array}{r}-5.3350 \\
(5.110)\end{array}$ & $\begin{array}{l}-0.6048^{* *} \\
(0.258)\end{array}$ \\
\hline Constant & $\begin{array}{l}0.5723^{* * *} \\
(0.101)\end{array}$ & $\begin{array}{l}1.7284^{* * *} \\
(0.152)\end{array}$ & $\begin{array}{r}0.0000 \\
(0.000)\end{array}$ & $\begin{array}{l}0.3587^{* * *} \\
(0.083)\end{array}$ & $\begin{array}{c}3.6483 \\
(3.243)\end{array}$ & $\begin{array}{l}0.6157^{* * *} \\
(0.173)\end{array}$ \\
\hline Observations & 12,331 & 12,331 & 7,783 & 7,775 & 7,775 & 7,775 \\
\hline R-squared & 0.010 & 0.023 & & 0.039 & 0.064 & \\
\hline Number of panels & & 4,418 & 3,120 & & 3,120 & 3,120 \\
\hline AR(1) test ( $p$-value) & & & 0.094 & & & 0.095 \\
\hline $\operatorname{AR}(2)$ test ( $p$-value) & & & 0.792 & & & 0.753 \\
\hline $\begin{array}{l}\text { Hansen test of over- } \\
\text { identification ( } p \text {-value) }\end{array}$ & & & 0.993 & & & 0.961 \\
\hline $\begin{array}{l}\text { Diff-in-Hansen tests of } \\
\text { exogeneity ( } p \text {-value) }\end{array}$ & & & 0.530 & & & 0.612 \\
\hline
\end{tabular}

Source: Authors' calculation from the SME surveys, 2007-2015

Notes: Robust standard errors in parentheses. The models also control for time dummies and ownership. ${ }^{* * *} p<0.01,{ }^{* *} p<0.05$, ${ }^{*} p<0.1$. Following Schultz, Tan, and Walsh (2010), and Wintoki et al. (2012), firm age and year dummies are considered to be exogenous. 
Table 3 presents the results of the effect of government support on firms' financial performance. Regarding the role of the government support covariate in determining firms' financial performance, pooled data estimations reveal that government assistance has a statistically insignificant influence on ROA. However, the results may be biased because of the absence of control for unobservable characteristics in the model. Attempting to control for time-invariant unobserved features and overcome the challenges noted above, we applied twostep dynamic GMM systems as guided by Wintoki et al. (2012). It should be noted that OLS and fixed effects methods may provide more efficient estimations than the GMM system if explanatory variables are not endogenous. Hence, a DurbinWu-Hausman test was implemented for all independent variables as a group if they are actually endogenous. According to Schultz et al. (2010), one-year lagged differences in explained covariates, such as $\Delta$ government support $_{i t-1}$, $\Delta$ firm size in $\log _{i t-1}, \Delta$ Innovation $_{i t-1}$, Bribe $_{i t-1}, \Delta$ Export $_{i t-1}$, and $\Delta$ leverage $_{i t-1}$, are considered instrumental variables, with year dummies and firm age in log considered as exogenous variables. The results of the test show that the null hypothesis is rejected at the traditional level of significance $(1 \%)$. The endogeneity of regressors is of concern, so it is necessary to apply the GMM system in this study (Durbin-WuHausman tests for endogeneity of covariates are used).

The results of the specification test are reported in Table 3. A serial correlation test of the AR(2) yields $p$-values of 0.792 and 0.753 . In addition, we determined the validity of the system GMM estimation by applying a Hansen-J test for overidentification. The result is displayed in the last row of Table 3. The $p$-values of the Hansen-J test are 0.993 and 0.961 . These results suggest that the GMM system instrumental variables used in this study are valid. In addition, Table 3 reports the results from an exogeneity test of a subset of our instruments that show a $p$-value of 0.53 and 0.612 . These results suggest that we cannot reject the hypothesis of the exogeneity of the additional subset of instruments used in the GMM system estimates.

Interestingly, a totally different picture emerges when using two-step GMM regression. As reported in Table 3 column 3, the effect of government support on firms' financial performance becomes significant after controlling for unobservable characteristics and dynamic endogeneity. This finding reflects the fact that the results from OLS regression are biased. Specifically, the estimated coefficient of government support shows that firms with government support achieve nearly $4 \%$ better financial performance than firms without such support. The positive, significant effect of government support on firms' financial performance is further confirmed in extended specifications and the results are displayed in columns 5 and 6 of Table 3. 
With regard to the impact of past firms' financial performance, the estimated results in Table 3 show a positive, significant effect on current performance, when unobservable factors are controlled for by using a dynamic two-step general system. This finding agrees with the empirical results of recent studies (e.g., Wintoki et al., 2012). These results show the importance of controlling for unobservable characteristics and also imply that past firms' financial performance is a vital variable in considering the dynamic nature of the factors affecting current performance. Ignoring this variable in the model can result in researchers failing to capture the real effect of government support on firms' financial performance.

To provide additional insight into the linkage between government support and firm financial performance, this study explores several additional scenarios. First, different types of government support may have various effects on firms' financial performance. Accordingly, this study explores the role of types of government support on firm performance. Interestingly, government technical support for trade activities, training of personnel and technology, has no statistically significant influence on firms' financial performance. However, government financial support has a positive influence on SME financial performance and obviously includes assistance such as tax exemptions, tax reductions, or loans from the Vietnam Development Bank (VDB) or Vietnam Bank for Social Policy with preferential interest rate support.

Table 4 shows that exporters tend to achieve better financial performance than nonexporters and this finding is consistent with previous studies (e.g., Vu, Holmes, Lim, \& Tran, 2014). Furthermore, the results of columns 3 of Table 4 also show the positive relationship between financial leverage and financial performance covered by the dynamic two-step GMM model when the potential sources of endogeneity and unobservable factors are taken into account. This finding supports the argument of González (2013), who suggests that a firm with higher financial debt may force directors into value-maximising decisions to cope with the higher debt pressure. Consequently, such actions improve firms' productivity and financial performance.

Second, many Vietnamese SMEs are not formally registered and government assistance programmes may depend on whether the firm is registered (Loayza, 1997). Accordingly, the linkage between government support and firms' financial performance is examined further in each sub-group, taking into account the formal status of firms. As one would expect, Table 4 shows that government financial assistance is beneficial for registered but not for unregistered firms. The reason may be that the informality may prevent firms from taking full advantage of 
government support (Loayza, 1997). In addition, the absence of account books and other required documents hinders unregistered firms from accessing and using these forms of support effectively (CIEM, 2010).

Table 4

The effect of types of government support on firms' financial performance

\begin{tabular}{|c|c|c|c|c|c|}
\hline \multirow{4}{*}{ Variables } & ROA & ROA & ROA & ROA & ROA \\
\hline & \multirow{2}{*}{ Pooled } & \multirow{2}{*}{ FE } & \multicolumn{3}{|c|}{ Dynamic GMM ${ }^{3}$} \\
\hline & & & Whole sample & Formal firms & Informal firms \\
\hline & (1) & $(2)$ & (3) & (4) & (5) \\
\hline lagROA & & & $\begin{array}{l}0.1481^{* *} \\
(0.015)\end{array}$ & $\begin{array}{c}0.0173^{*} \\
(0.008)\end{array}$ & $\begin{array}{c}0.0332 \\
(0.090)\end{array}$ \\
\hline Financial support & $\begin{array}{c}-0.0059 \\
(0.022)\end{array}$ & $\begin{array}{c}0.0068 \\
(0.031)\end{array}$ & $\begin{array}{l}0.0383^{* *} \\
(0.015)\end{array}$ & $\begin{array}{l}0.0177+ \\
(0.010)\end{array}$ & $\begin{array}{c}-0.0760 \\
(0.211)\end{array}$ \\
\hline Technical support & $\begin{array}{c}-0.0620+ \\
(0.032)\end{array}$ & $\begin{array}{c}-0.0123 \\
(0.043)\end{array}$ & $\begin{array}{c}-0.0103 \\
(0.034)\end{array}$ & $\begin{array}{c}-0.0099 \\
(0.023)\end{array}$ & $\begin{array}{c}-0.0811 \\
(0.230)\end{array}$ \\
\hline Innovation & $\begin{array}{c}-0.0344^{*} \\
(0.017)\end{array}$ & $\begin{array}{c}-0.0087 \\
(0.018)\end{array}$ & $\begin{array}{c}-0.0138 \\
(0.012)\end{array}$ & $\begin{array}{c}-0.0254^{* *} \\
(0.008)\end{array}$ & $\begin{array}{c}-0.1119 \\
(0.265)\end{array}$ \\
\hline Bribes & $\begin{array}{c}-0.0578^{* *} \\
(0.014)\end{array}$ & $\begin{array}{c}-0.0183 \\
(0.020)\end{array}$ & $\begin{array}{c}-0.0221^{*} \\
(0.010)\end{array}$ & $\begin{array}{c}-0.0144 \\
(0.007)\end{array}$ & $\begin{array}{c}-0.0584 \\
(0.060)\end{array}$ \\
\hline Export & $\begin{array}{l}0.1294^{* *} \\
(0.038)\end{array}$ & $\begin{array}{c}0.0363 \\
(0.058)\end{array}$ & $\begin{array}{l}0.0607^{* *} \\
(0.022)\end{array}$ & $\begin{array}{c}0.0084 \\
(0.010)\end{array}$ & $\begin{array}{r}0.1011 \\
(0.439)\end{array}$ \\
\hline Firm size in log & $\begin{array}{c}-0.0468^{* *} \\
(0.013)\end{array}$ & $\begin{array}{c}-0.0358 \\
(0.053)\end{array}$ & $\begin{array}{c}0.0054 \\
(0.014)\end{array}$ & $\begin{array}{c}0.0050 \\
(0.009)\end{array}$ & $\begin{array}{c}-0.0255 \\
(0.103)\end{array}$ \\
\hline Firm age in log & $\begin{array}{c}-0.0580^{* *} \\
(0.019)\end{array}$ & $\begin{array}{c}-0.0084 \\
(0.020)\end{array}$ & $\begin{array}{c}-0.0384+ \\
(0.020)\end{array}$ & $\begin{array}{c}-0.0261^{\text {** }} \\
(0.010)\end{array}$ & $\begin{array}{c}-0.0589 \\
(0.084)\end{array}$ \\
\hline Leverage & $\begin{array}{l}0.2920^{* *} \\
(0.092)\end{array}$ & $\begin{array}{c}0.1390^{*} \\
(0.056)\end{array}$ & $\begin{array}{c}0.0542^{*} \\
(0.026)\end{array}$ & $\begin{array}{l}0.1200^{* *} \\
(0.024)\end{array}$ & $\begin{array}{c}0.5223 \\
(0.958)\end{array}$ \\
\hline Tobacco sector & $\begin{array}{c}-0.2950^{* *} \\
(0.043)\end{array}$ & $\begin{array}{c}-1.9269 \\
(1.853)\end{array}$ & $\begin{array}{c}-0.5556^{* *} \\
(0.214)\end{array}$ & $\begin{array}{c}-0.2757+ \\
(0.143)\end{array}$ & $\begin{array}{c}-0.7972 \\
(2.093)\end{array}$ \\
\hline Textiles sector & $\begin{array}{c}-0.1945^{* *} \\
(0.041)\end{array}$ & $\begin{array}{c}-1.6008 \\
(1.710)\end{array}$ & $\begin{array}{c}-0.3669^{\text {** }} \\
(0.100)\end{array}$ & $\begin{array}{c}0.0020 \\
(0.052)\end{array}$ & $\begin{array}{c}-1.0619 \\
(2.720)\end{array}$ \\
\hline Apparel sector & $\begin{array}{c}-0.0592 \\
(0.050)\end{array}$ & $\begin{array}{c}-1.7371 \\
(1.687)\end{array}$ & $\begin{array}{c}-0.4907^{* *} \\
(0.093)\end{array}$ & $\begin{array}{c}-0.5039^{* *} \\
(0.103)\end{array}$ & $\begin{array}{c}-1.8866 \\
(3.740)\end{array}$ \\
\hline Leather sector & $\begin{array}{c}-0.1331^{* *} \\
(0.047)\end{array}$ & $\begin{array}{c}-1.8848 \\
(1.740)\end{array}$ & $\begin{array}{c}-0.3284^{* *} \\
(0.117)\end{array}$ & $\begin{array}{c}-0.2229^{* *} \\
(0.068)\end{array}$ & $\begin{array}{c}-0.7209 \\
(2.384)\end{array}$ \\
\hline Wood sector & $\begin{array}{c}-0.1696^{* *} \\
(0.031)\end{array}$ & $\begin{array}{c}-1.8036 \\
(1.757)\end{array}$ & $\begin{array}{c}-0.3633^{* *} \\
(0.083)\end{array}$ & $\begin{array}{c}-0.0944^{* *} \\
(0.033)\end{array}$ & $\begin{array}{c}-0.9266 \\
(2.598)\end{array}$ \\
\hline Paper sector & $\begin{array}{c}-0.1603^{* *} \\
(0.031)\end{array}$ & $\begin{array}{c}-1.4518 \\
(1.401)\end{array}$ & $\begin{array}{c}-0.5302^{* *} \\
(0.139)\end{array}$ & $\begin{array}{c}-0.1462^{* *} \\
(0.047)\end{array}$ & $\begin{array}{c}-1.2309 \\
(4.483)\end{array}$ \\
\hline
\end{tabular}


Table 4 (continued)

\begin{tabular}{|c|c|c|c|c|c|}
\hline \multirow{4}{*}{ Variables } & ROA & ROA & ROA & ROA & ROA \\
\hline & \multirow{2}{*}{ Pooled } & \multirow{2}{*}{ FE } & \multicolumn{3}{|c|}{ Dynamic GMM ${ }^{3}$} \\
\hline & & & Whole sample & Formal firms & Informal firms \\
\hline & (1) & (2) & (3) & (4) & (5) \\
\hline $\begin{array}{l}\text { Publishing and printing } \\
\text { sector }\end{array}$ & $\begin{array}{l}-0.1307^{* *} \\
(0.046)\end{array}$ & $\begin{array}{c}-1.6246 \\
(1.616)\end{array}$ & $\begin{array}{l}-0.4624^{* *} \\
(0.130)\end{array}$ & $\begin{array}{c}-0.0971 \\
(0.056)\end{array}$ & $\begin{array}{c}-0.6273 \\
(2.072)\end{array}$ \\
\hline Refined petroleum sector & $\begin{array}{l}-0.2773^{* *} \\
(0.049)\end{array}$ & $\begin{array}{c}-1.6741 \\
(1.648)\end{array}$ & $\begin{array}{l}-0.3153^{* *} \\
(0.084)\end{array}$ & $\begin{array}{c}-0.0828 \\
(0.065)\end{array}$ & $\begin{array}{c}-0.9575 \\
(2.326)\end{array}$ \\
\hline Chemical products sector & $\begin{array}{l}-0.1917^{* *} \\
(0.041)\end{array}$ & $\begin{array}{l}-1.7866 \\
(1.725)\end{array}$ & $\begin{array}{c}-0.4794^{*} \\
(0.215)\end{array}$ & $\begin{array}{l}-0.1377^{*} \\
(0.061)\end{array}$ & $\begin{array}{c}-0.6433 \\
(2.227)\end{array}$ \\
\hline Rubber sector & $\begin{array}{l}-0.1379^{* *} \\
(0.042)\end{array}$ & $\begin{array}{c}-1.8942 \\
(1.793)\end{array}$ & $\begin{array}{l}-0.5242^{* *} \\
(0.118)\end{array}$ & $\begin{array}{c}0.0093 \\
(0.049)\end{array}$ & $\begin{array}{l}-1.1250 \\
(2.352)\end{array}$ \\
\hline $\begin{array}{l}\text { Non-metallic mineral } \\
\text { products sector }\end{array}$ & $\begin{array}{l}-0.1472^{* *} \\
(0.034)\end{array}$ & $\begin{array}{l}-2.0169 \\
(2.050)\end{array}$ & $\begin{array}{l}-0.4501^{* *} \\
(0.123)\end{array}$ & $\begin{array}{c}-0.0508 \\
(0.054)\end{array}$ & $\begin{array}{r}-0.4941 \\
(2.249)\end{array}$ \\
\hline Basic metals sector & $\begin{array}{c}-0.0838 \\
(0.105)\end{array}$ & $\begin{array}{l}-2.4452 \\
(2.361)\end{array}$ & $\begin{array}{l}-0.6772^{* *} \\
(0.126)\end{array}$ & $\begin{array}{c}0.0114 \\
(0.056)\end{array}$ & $\begin{array}{c}-1.7575 \\
(4.013)\end{array}$ \\
\hline $\begin{array}{l}\text { Fabricated metal products } \\
\text { sector }\end{array}$ & $\begin{array}{l}-0.1281^{* *} \\
(0.034)\end{array}$ & $\begin{array}{l}-2.4767 \\
(2.432)\end{array}$ & $\begin{array}{l}-0.5519^{* *} \\
(0.119)\end{array}$ & $\begin{array}{r}0.0437 \\
(0.042)\end{array}$ & $\begin{array}{c}-2.0708 \\
(4.638)\end{array}$ \\
\hline $\begin{array}{l}\text { Electronic machinery, } \\
\text { computers, radio sector }\end{array}$ & $\begin{array}{l}-0.1554^{* *} \\
(0.039)\end{array}$ & $\begin{array}{l}-2.3454 \\
(2.268)\end{array}$ & $\begin{array}{l}-0.6846^{* *} \\
(0.144)\end{array}$ & $\begin{array}{l}-0.1316^{* *} \\
(0.045)\end{array}$ & $\begin{array}{c}-1.4486 \\
(3.403)\end{array}$ \\
\hline Motor vehicles sector & $\begin{array}{l}-0.2197^{* *} \\
(0.046)\end{array}$ & $\begin{array}{l}-2.3985 \\
(2.247)\end{array}$ & $\begin{array}{l}-0.4118^{* *} \\
(0.137)\end{array}$ & $\begin{array}{c}0.0799 \\
(0.071)\end{array}$ & $\begin{array}{c}-2.7431 \\
(6.647)\end{array}$ \\
\hline $\begin{array}{l}\text { Other transport equipment } \\
\text { sector }\end{array}$ & $\begin{array}{l}-0.1904^{* *} \\
(0.070)\end{array}$ & $\begin{array}{l}-2.4219 \\
(2.310)\end{array}$ & $\begin{array}{l}-0.4847^{* *} \\
(0.105)\end{array}$ & $\begin{array}{l}-0.2095^{* *} \\
(0.041)\end{array}$ & $\begin{array}{l}-0.8924 \\
(2.322)\end{array}$ \\
\hline $\begin{array}{l}\text { Furniture, jewellery, music } \\
\text { equipment sector }\end{array}$ & $\begin{array}{l}-0.1727^{* *} \\
(0.035)\end{array}$ & $\begin{array}{r}-1.8165 \\
(1.800)\end{array}$ & $\begin{array}{l}-0.3895^{* *} \\
(0.088)\end{array}$ & $\begin{array}{c}-0.0298 \\
(0.035)\end{array}$ & $\begin{array}{l}-1.0679 \\
(2.772)\end{array}$ \\
\hline Recycling sector & $\begin{array}{l}-0.2128^{* *} \\
(0.078)\end{array}$ & $\begin{array}{l}-2.4571 \\
(2.328)\end{array}$ & $\begin{array}{l}-0.6073^{* *} \\
(0.087)\end{array}$ & $\begin{array}{l}-0.1383^{* *} \\
(0.027)\end{array}$ & $\begin{array}{c}-0.8489 \\
(1.850)\end{array}$ \\
\hline Constant & $\begin{array}{l}0.5829^{* *} \\
(0.104)\end{array}$ & $\begin{array}{r}1.7202 \\
(1.483)\end{array}$ & $\begin{array}{c}0.0000 \\
(0.000)\end{array}$ & $\begin{array}{l}0.3065^{* *} \\
(0.045)\end{array}$ & $\begin{array}{r}1.3321 \\
(2.552)\end{array}$ \\
\hline Observations & 12,322 & 12,322 & 7,775 & 4,263 & 1,905 \\
\hline R-squared & 0.014 & 0.024 & & & \\
\hline Number of panels & & 4,417 & 3,120 & 2,005 & 985 \\
\hline AR(1) test ( $p$-value) & & & 0.080 & 0.003 & 0.692 \\
\hline AR(2) test ( $p$-value) & & & 0.751 & 0.520 & 0.935 \\
\hline $\begin{array}{l}\text { Hansen test of over- } \\
\text { identification ( } p \text {-value) }\end{array}$ & & & 0.934 & 0.661 & 0.764 \\
\hline $\begin{array}{l}\text { Diff-in-Hansen tests of } \\
\text { exogeneity ( } p \text {-value) }\end{array}$ & & & 0.527 & 0.320 & 0.380 \\
\hline
\end{tabular}

Source: Authors' calculation from the SME surveys, 2007-2015

Notes: Robust standard errors in parentheses. The model also controls for time dummies and ownership. ${ }^{* *} p<0.01,{ }^{*} p<0.05$, $+p<0.1$. Following Schultz et al. (2010) and Wintoki et al. (2012), firm age and year dummies are considered to be exogenous. 
As a final step, the robustness of the results is checked by conducting several scenarios. First, as documented by Wong and Hooy (2018), political connections are typical in countries with weak protection of property rights and in developing countries. In addition, some studies show that our results may be biased, ignoring the role of political connections in investigating the relationship between government support and firms' financial performance (e.g., Zhang et al., 2014). ${ }^{4}$ Consequently, in further regressions, a political connection index is added. Furthermore, the measure of firms' financial performance (ROA) is replaced by ROE (return on equity). However, the positive effects of government support on firms' financial performance are still recorded and the results are reported in Table 5.

Table 5

Robustness check

\begin{tabular}{lcccc}
\hline \multirow{2}{*}{ Variables } & ROA & ROE & ROA & ROE \\
\cline { 2 - 5 } & $(1)$ & $(2)$ & $(3)$ & $(4)$ \\
\hline lagROA & $0.1477^{* *}$ & & $0.1506^{* *}$ & \\
lagROE & $(0.073)$ & & $(0.074)$ & \\
Government support & & -0.0064 & & -0.0062 \\
& & $(0.005)$ & & $(0.005)$ \\
Financial support & $0.0390^{*}$ & $0.0401^{*}$ & & \\
Technical support & $(0.022)$ & $(0.022)$ & & \\
Firm size in log & & & $0.0436^{*}$ & $0.0472^{*}$ \\
Firm age in log & & & $(0.024)$ & $(0.026)$ \\
& & & -0.0164 & -0.0343 \\
Innovation & & & $(0.056)$ & $(0.063)$ \\
Bribes & 0.0078 & -0.0270 & 0.0067 & -0.0259 \\
Export & $(0.019)$ & $(0.034)$ & $(0.019)$ & $(0.035)$ \\
& -0.0262 & -0.0686 & -0.0303 & $-0.0705^{*}$ \\
Leverage & $(0.031)$ & $(0.044)$ & $(0.035)$ & $(0.042)$ \\
& -0.0066 & -0.0083 & -0.0091 & -0.0098 \\
& $(0.018)$ & $(0.020)$ & $(0.017)$ & $(0.020)$ \\
& $-0.0224^{*}$ & -0.0140 & $-0.0228^{*}$ & -0.0139 \\
& $(0.013)$ & $(0.017)$ & $(0.014)$ & $(0.017)$ \\
& 0.0668 & -0.0047 & 0.0665 & -0.0036 \\
& $(0.067)$ & $(0.038)$ & $(0.063)$ & $(0.039)$ \\
& 0.0635 & 0.3262 & 0.0631 & 0.3100 \\
& $(0.069)$ & $(0.374)$ & $(0.066)$ & $(0.370)$ \\
& -0.0143 & 0.0534 & -0.0118 & 0.0605 \\
& $(0.059)$ & $(0.063)$ & $(0.069)$ & $(0.064)$ \\
\hline
\end{tabular}

(continued on next page) 
Table 5 (continued)

\begin{tabular}{|c|c|c|c|c|}
\hline \multirow{2}{*}{ Variables } & ROA & ROE & ROA & ROE \\
\hline & (1) & (2) & (3) & (4) \\
\hline Tobacco sector & $\begin{array}{c}-0.6366^{*} \\
(0.352)\end{array}$ & $\begin{array}{l}-0.7003 \\
(0.479)\end{array}$ & $\begin{array}{c}-0.6159^{*} \\
(0.318)\end{array}$ & $\begin{array}{l}-0.7300 \\
(0.487)\end{array}$ \\
\hline Textiles sector & $\begin{array}{l}-0.4084^{* * *} \\
(0.145)\end{array}$ & $\begin{array}{l}-0.6191^{* *} \\
(0.275)\end{array}$ & $\begin{array}{l}-0.3944^{* * *} \\
(0.147)\end{array}$ & $\begin{array}{c}-0.6124^{* *} \\
(0.278)\end{array}$ \\
\hline Apparel sector & $\begin{array}{l}-0.5203^{* * *} \\
(0.154)\end{array}$ & $\begin{array}{c}-0.7390^{* *} \\
(0.344)\end{array}$ & $\begin{array}{l}-0.5202^{* * *} \\
(0.167)\end{array}$ & $\begin{array}{c}-0.7341^{* *} \\
(0.356)\end{array}$ \\
\hline Leather sector & $\begin{array}{c}-0.3674^{* *} \\
(0.181)\end{array}$ & $\begin{array}{r}-0.5349^{*} \\
(0.283)\end{array}$ & $\begin{array}{r}-0.3432^{*} \\
(0.184)\end{array}$ & $\begin{array}{r}-0.5316^{*} \\
(0.301)\end{array}$ \\
\hline Wood sector & $\begin{array}{c}-0.3891^{* * *} \\
(0.101)\end{array}$ & $\begin{array}{l}-0.6052^{* * *} \\
(0.205)\end{array}$ & $\begin{array}{c}-0.3892^{* * *} \\
(0.113)\end{array}$ & $\begin{array}{l}-0.6122^{* * *} \\
(0.217)\end{array}$ \\
\hline Paper sector & $\begin{array}{c}-0.5528^{* * *} \\
(0.210)\end{array}$ & $\begin{array}{c}-0.7671^{* *} \\
(0.343)\end{array}$ & $\begin{array}{c}-0.5663^{* * *} \\
(0.217)\end{array}$ & $\begin{array}{c}-0.7650^{* *} \\
(0.343)\end{array}$ \\
\hline Publishing and printing sector & $\begin{array}{l}-0.4896^{* *} \\
(0.226)\end{array}$ & $\begin{array}{r}-0.6565^{*} \\
(0.352)\end{array}$ & $\begin{array}{c}-0.4952^{* *} \\
(0.214)\end{array}$ & $\begin{array}{c}-0.6647^{*} \\
(0.347)\end{array}$ \\
\hline Refined petroleum sector & $\begin{array}{l}-0.3305^{* *} \\
(0.152)\end{array}$ & $\begin{array}{c}-0.5213^{* *} \\
(0.221)\end{array}$ & $\begin{array}{c}-0.3285^{* *} \\
(0.161)\end{array}$ & $\begin{array}{l}-0.5175^{* *} \\
(0.226)\end{array}$ \\
\hline Chemical products sector & $\begin{array}{l}-0.4505^{* *} \\
(0.228)\end{array}$ & $\begin{array}{r}-0.9466^{*} \\
(0.507)\end{array}$ & $\begin{array}{c}-0.4894^{* *} \\
(0.232)\end{array}$ & $\begin{array}{c}-0.9402^{*} \\
(0.493)\end{array}$ \\
\hline Rubber sector & $\begin{array}{c}-0.5690^{* * *} \\
(0.180)\end{array}$ & $\begin{array}{c}-0.7893^{* *} \\
(0.337)\end{array}$ & $\begin{array}{l}-0.5519^{* * *} \\
(0.169)\end{array}$ & $\begin{array}{r}-0.7830^{* *} \\
(0.328)\end{array}$ \\
\hline $\begin{array}{l}\text { Non-metallic mineral products } \\
\text { sector }\end{array}$ & $\begin{array}{l}-0.4720^{* * *} \\
(0.141)\end{array}$ & $\begin{array}{c}-0.6876^{* *} \\
(0.267)\end{array}$ & $\begin{array}{l}-0.4784^{* * *} \\
(0.159)\end{array}$ & $\begin{array}{c}-0.6984^{* *} \\
(0.285)\end{array}$ \\
\hline Basic metals sector & $\begin{array}{l}-0.6956^{* *} \\
(0.306)\end{array}$ & $\begin{array}{c}-0.8898^{* *} \\
(0.451)\end{array}$ & $\begin{array}{c}-0.6919^{* *} \\
(0.333)\end{array}$ & $\begin{array}{c}-0.8966^{* *} \\
(0.449)\end{array}$ \\
\hline $\begin{array}{l}\text { Manufactured metal products } \\
\text { sector }\end{array}$ & $\begin{array}{l}-0.5667^{* *} \\
(0.246)\end{array}$ & $\begin{array}{c}-0.8354^{* *} \\
(0.418)\end{array}$ & $\begin{array}{c}-0.5714^{* *} \\
(0.262)\end{array}$ & $\begin{array}{c}-0.8329^{* *} \\
(0.413)\end{array}$ \\
\hline $\begin{array}{l}\text { Electronic machinery, } \\
\text { computers, radio sector }\end{array}$ & $\begin{array}{l}-0.7187^{* *} \\
(0.301)\end{array}$ & $\begin{array}{r}-0.9588^{*} \\
(0.527)\end{array}$ & $\begin{array}{l}-0.7307^{* *} \\
(0.298)\end{array}$ & $\begin{array}{c}-0.9750^{*} \\
(0.517)\end{array}$ \\
\hline Motor vehicles sector & $\begin{array}{c}-0.4463^{*} \\
(0.249)\end{array}$ & $\begin{array}{r}-0.6223^{*} \\
(0.323)\end{array}$ & $\begin{array}{r}-0.4422^{*} \\
(0.255)\end{array}$ & $\begin{array}{c}-0.6167^{*} \\
(0.324)\end{array}$ \\
\hline $\begin{array}{l}\text { Other transport equipment } \\
\text { sector }\end{array}$ & $\begin{array}{l}-0.5116^{* *} \\
(0.223)\end{array}$ & $\begin{array}{c}-0.7663^{*} \\
(0.417)\end{array}$ & $\begin{array}{c}-0.4992^{* *} \\
(0.239)\end{array}$ & $\begin{array}{c}-0.7467^{*} \\
(0.410)\end{array}$ \\
\hline $\begin{array}{l}\text { Furniture, jewellery, music } \\
\text { equipment sector }\end{array}$ & $\begin{array}{l}-0.4179^{* * *} \\
(0.114)\end{array}$ & $\begin{array}{l}-0.6167^{* * *} \\
(0.212)\end{array}$ & $\begin{array}{l}-0.4149^{* * *} \\
(0.125)\end{array}$ & $\begin{array}{l}-0.6193^{* * *} \\
(0.223)\end{array}$ \\
\hline Recycling sector & $\begin{array}{c}-0.6371^{* * *} \\
(0.239)\end{array}$ & $\begin{array}{c}-0.8078^{* * *} \\
(0.265)\end{array}$ & $\begin{array}{c}-0.6366^{* * *} \\
(0.243)\end{array}$ & $\begin{array}{l}-0.8117^{* * *} \\
(0.274)\end{array}$ \\
\hline
\end{tabular}


Hoai Thu Thi Nguyen et al.

Table 5 (continued)

\begin{tabular}{lcccc}
\hline \multirow{2}{*}{ Variables } & ROA & ROE & ROA & ROE \\
\cline { 2 - 5 } & $(1)$ & $(2)$ & $(3)$ & $(4)$ \\
\hline Constant & $0.6157^{* * *}$ & $1.0022^{* * *}$ & $0.6349^{* * *}$ & 0.0000 \\
& $(0.168)$ & $(0.319)$ & $(0.189)$ & $(0.000)$ \\
\hline Observations & 7,775 & 7,772 & 7,775 & 7,772 \\
Number of panels & 3,120 & 3,118 & 3,120 & 3,118 \\
AR(1) test ( $p$-value) & 0.093 & 0.032 & 0.093 & 0.031 \\
AR(2) test $(p$-value) & 0.758 & 0.876 & 0.771 & 0.882 \\
Hansen test of over- & 0.959 & 0.996 & 0.921 & 0.997 \\
identification $(p$-value) & & & & \\
Diff-in-Hansen tests of & 0.560 & 0.854 & 0.466 & 0.852 \\
exogeneity $(p$-value) & & & & \\
\hline
\end{tabular}

Source: Authors' calculation from the SME surveys, 2007-2015

Notes: Robust standard errors in parentheses. The model also controls for time dummies and ownership. ${ }^{* * *} p<0.01,{ }^{* *} p<0.05,{ }^{*} p<0.1$. Following Schultz et al. (2010) and Wintoki et al. (2012), firm age and year dummies are considered to be exogenous. Models are estimated using dynamic GMM

\section{CONCLUSION AND POLICY IMPLICATIONS}

Aiming to contribute to the small but growing amount of empirical evidence concerning the linkage between government support and financial performance, this study contributes to the existing literature by providing the first evidence of the influence on SME financial performance exerted not only by government support but also by types of government subsidy. Based on the empirical results, some of the main findings may be summarised as follows.

Regarding traditional firm characteristic factors, the empirical results are generally consistent with other international empirical studies. For example, exporters who sell in both markets achieve a higher financial performance than non-exporters. In addition, leverage has a positive association with firms' financial performance. Furthermore, it is not surprising that firms marked by corrupt behaviour turn in a lower financial performance than their counterparts that are free of it.

With regard to the connection between government support and firms' financial performance, estimates of the OLS indicate that there is no linkage between the two. However, dynamic two-step GMM estimates reveal that government support has a positive influence on firms' financial performance. Also, GMM approaches show that while financial assistance shows a positive association, technical support proves to be a negative link with firms' financial performance. This suggests that 
the effect of government support on firms' financial performance varies depending on type of subsidy.

Regarding policy implications, changes in government financial support for firms are accompanied by an improvement in firms' financial performance. This finding implies that private Vietnamese SMEs are often small so that the cancellation of subsidies will have a negative impact on both their growth and financial performance. Our results further show that financial support rather than technical assistance has a positive effect on firms' financial performance. This suggests that it is very important to focus on tax exemptions, interest rate subsidies, and investment incentives since these may help private SMEs improve their growth and financial performance, especially in the present context of discrimination against non-state SMEs.

Vietnam is considered to be a successful example of a transitional economy, having shifted from a centrally planned economy to a market-oriented one with an annual average GDP growth rate of 6.8\% during the 1986-2009 period (Le, 2010). Also, according to the World Bank (2012), Vietnam's poverty rate fell from nearly $60 \%$ in the early 1990 s to $20.7 \%$ in 2010 . Accordingly, Vietnamese government policy may offer a good example for other transitional economies with similar characteristics and conditions.

There are some limitations to the current study. It uses data from manufacturing SMEs, so its findings may not be representative for other enterprises. In particular, the findings may not be true for large enterprises which command various resources and business approaches, including markets and negotiating power. This suggests that further research on larger firms and other sectors beyond manufacturing should be carried out to draw general conclusions about the relationship between government support and firms' financial performance.

\section{ACKNOWLEDGEMENTS}

The authors would like to thank the Vietnam National Foundation for Science and Technology Development (NAFOSTED) for funding this research under grant number 502.01-2016.11. 


\section{NOTES}

1. For more details concerning data, see Cuong, Rand, Silva, Tam, and Tarp (2008).

2. Definitions and measurements of the variables in Table 2 are explained in Appendix.

3. According to Rand and Torm (2012), formal firms are firms that are registered to pay taxes (have a tax code).

4. According to Li, Meng, Wang, and Zhou (2008), political connection is measured as a dummy variable, taking the value 1 if the firm owners/managers are members of the Communist Party of Vietnam (CPV), and zero otherwise.

\section{APPENDIX}

Definitions and measurements of variables in the models

\begin{tabular}{|c|c|c|}
\hline Variables & Definition & Measurement \\
\hline \multicolumn{3}{|l|}{ Dependent variables } \\
\hline ROA & Ratio of net profit to total assets & Continuous variable \\
\hline ROE & Ratio of net profit to total equity & Continuous variable \\
\hline \multicolumn{3}{|l|}{ Explanatory variables } \\
\hline Government support & $\begin{array}{l}1 \text { if firms received support from the } \\
\text { government, } 0 \text { otherwise }\end{array}$ & Dummy variable \\
\hline Financial support & $\begin{array}{l}1 \text { if firms received tax exemptions or } \\
\text { reductions or loans with preferred } \\
\text { interest from the government, } 0 \text { otherwise }\end{array}$ & Dummy variable \\
\hline Technical support & $\begin{array}{l}1 \text { if firms benefited from a human resource } \\
\text { training programme, trade promotion } \\
\text { programme, or quality assurance } \\
\text { programmes from the government, } \\
0 \text { otherwise }\end{array}$ & Dummy variable \\
\hline Innovation & $\begin{array}{l}1 \text { if firms introduced new products, applied } \\
\text { new technology, or modified existing } \\
\text { products, } 0 \text { otherwise }\end{array}$ & Dummy variable \\
\hline Bribes & $\begin{array}{l}1 \text { if firms had to pay informal fees to do } \\
\text { business, } 0 \text { otherwise }\end{array}$ & Dummy variable \\
\hline Export & $\begin{array}{l}1 \text { if firms participated in export markets, } \\
0 \text { otherwise }\end{array}$ & Dummy variable \\
\hline Firm size & Total employment & Continuous variable \\
\hline Firm age & Number of years since establishment & Continuous variable \\
\hline Leverage & Ratio between total debt and total assets & Continuous variable \\
\hline
\end{tabular}




\section{REFERENCES}

Anh, N.N., Mai, N.P., Nhat, N.D., \& Chuc, N.D. (2011). Trade liberalization and innovation linkages: Micro-evidence from Vietnam SME surveys. Retrieved 5 January 2018 from http://www.eria.org/publications/research_project_reports/ images/pdf/y2010/no4/All_Pages_Micro_data_Y2010.pdf

Adams, R.B., \& Ferreira, D. (2009). Women in the boardroom and their impact on governance and performance. Journal of Financial Economics, 94(2), 291-309. https://doi.org/10.1016/j.jfineco.2008.10.007

Barajas, A., Huergo, E., \& Moreno, L. (2017). Public support to business R\&D and the economic crisis: Spanish evidence. Retrieved 10 February 2018 from https://mpra.ub.uni-muenchen.de/81529/

Blundell, R., \& Bond, S. (1998). Initial conditions and moment restrictions in dynamic panel data models. Journal of Econometrics, 87(1), 115-143. https://doi.org/10.1016/ S0304-4076(98)00009-8

CIEM (Central Institute for Economic Management). (2010). Characteristics of the Vietnamese business environment: Evidence from a SME survey in 2009. Hanoi: CIEM.

Cuong, T.T., Rand, J., Silva, P., Tam, N.T., \& Tarp, F. (2008). Dac diem moi truong kinh doanh o Vietnam/Characteristics of the Vietnamese business environment: Evidence from a SME survey in 2007. Hanoi: CIEM.

Cowling, M. (2010). The role of loan guarantee schemes in alleviating credit rationing in the UK. Journal of Financial Stability, 6(1), 36-44. https://doi.org/10.1016/j. jfs.2009.05.007

Doh, S., \& Kim, B. (2014). Government support for SME innovations in the regional industries: The case of government financial support program in South Korea. Research Policy, 43(9), 1557-1569. https://doi.org/10.1016/j.respol.2014.05.001

Fajnzylber, P., Maloney, W.F., \& Montes-Rojas, G.V. (2009). Releasing constraints to growth or pushing on a string? Policies and performance of Mexican microfirms. The Journal of Development Studies, 45(7), 1027-1047. https://doi. org $/ 10.1080 / 00220380802264911$

Flannery, M.J., \& Hankins, K.W. (2013). Estimating dynamic panel models in corporate finance. Journal of Corporate Finance, 19, 1-19. https://doi.org/10.1016/j. jcorpfin.2012.09.004

González, V.M. (2013). Leverage and corporate performance: International evidence. International Review of Economics \& Finance, 25, 169-184. https://doi.org/ 10.1016/j.iref.2012.07.005

Hansen, H., Rand, J., \& Tarp, F. (2009). Enterprise growth and survival in Vietnam: Does government support matter? The Journal of Development Studies, 45(7), 10481069. https://doi.org/10.1080/00220380902811025

Honjo, Y., \& Harada, N. (2006). SME policy, financial structure and firm growth: Evidence from Japan. Small Business Economics, 27(4-5), 289-300. https://doi. org/10.1007/s11187-005-6703-0 
Le, C.L.V. (2010). Technical efficiency performance of Vietnamese manufacturing small and medium enterprises. Unpublished $\mathrm{PhD}$ dissertation, University of Wollongong, NSW, Australia.

Lerner, J. (1999). The government as venture capitalist: The long-run impact of the SBIR program. Journal of Business, 3(72), 285-318. https://doi.org/10.1086/209616

Li, H., Meng, L., Wang, Q., \& Zhou, L.A. (2008). Political connections, financing and firm performance: Evidence from Chinese private firms. Journal of Development Economics, 87(2), 283-299. https://doi.org/10.1016/j.jdeveco.2007.03.001

Loayza, N.V. (1997). The economics of the informal sector: A simple model and some empirical evidence from Latin America. Policy Research Working Paper WPS 1727. Washington, DC: The World Bank. Retrieved 15 February 2018 from http://documents.worldbank.org/curated/en/685181468743710751/Theeconomics-of-the-informal-sector-a-simple-model-and-some-empiricalevidence-from-Latin-America

Maggioni, V., Sorrentino, M., \& Williams, M. (1999). Mixed consequences of government aid for new venture creation: Evidence from Italy. Journal of Management and Governance, 3(3), 287-305. https://doi.org/10.1023/A:1009922725925

Morris, M., \& Stevens, P. (2010). Evaluation of a New Zealand business support programme using firm performance micro-data. Small Enterprise Research, 17(1), 30-42. https://doi.org/10.5172/ser.17.1.30

Nguyen, T.T., \& Van Dijk, M.A. (2012). Corruption, growth, and governance: Private vs. state-owned firms in Vietnam. Journal of Banking \& Finance, 36(11), 29352948. https://doi.org/10.1016/j.jbankfin.2012.03.027

Rand, J., \& Torm, N. (2012). The benefits of formalization: Evidence from Vietnamese manufacturing SMEs. World Development, 40(5), 983-998. https://oi.org/ 10.1016/j.worlddev.2011.09.004

Rotger, G.P., Gørtz, M., \& Storey, D.J. (2012). Assessing the effectiveness of guided preparation for new venture creation and performance: Theory and practice. Journal of Business Venturing, 27(4), 506-521. https://doi.org/10.1016/j. jbusvent.2012.01.003

Schultz, E.L., Tan, D.T., \& Walsh, K.D. (2010). Endogeneity and the corporate governanceperformance relation. Australian Journal of Management, 35(2), 145-163. https://doi.org/10.1177/0312896210370079

Takalo, T., \& Tanayama, T. (2010). Adverse selection and financing of innovation: Is there a need for R\&D subsidies? The Journal of Technology Transfer, 35(1), 16-41. https://doi.org/10.1007/s10961-009-9112-8

Vu, H.V., Holmes, M., Tran, T.Q., \& Lim, S. (2016). Firm exporting and productivity: What if productivity is no longer a black box. Baltic Journal of Economics, 16(2), 95-113. https://doi.org/10.1080/1406099X.2016.1187382

Vu, H.V., Tran, T.Q., Nguyen, T.V., \& Lim, S. (2018). Corruption, types of corruption and firm financial performance: New evidence from a transitional economy. Journal of Business Ethics, 148(4), 847-858. https://doi.org/10.1007/s10551-016-3016-y

Vu, H., Holmes, M., Lim, S., \& Tran, T. (2014). Exports and profitability: A note from quantile regression approach. Applied Economics Letters, 21(6), 442-445. https://doi.org/10.1080/13504851.2013.866197 
Wei, J., \& Liu, Y. (2015). Government support and firm innovation performance: Empirical analysis of 343 innovative enterprises in China. Chinese Management Studies, 9(1), 38-55. https://doi.org/10.1108/CMS-01-2015-0018

Wintoki, M.B., Linck, J.S., \& Netter, J.M. (2012). Endogeneity and the dynamics of internal corporate governance. Journal of Financial Economics, 105(3), 581-606. https://doi.org/10.1016/j.jfineco.2012.03.005

Wong, W.-Y., \& Hooy, C.-W. (2018). Do types of political connection affect firm performance differently? Pacific-Basin Finance Journal, 51, 297-317. https://doi. org/10.1016/j.pacfin.2018.08.009

Wooldridge, J.M. (2009). Introductory econometrics: A modern approach. Mason, OH: Cengage Learning.

World Bank. (2012). Well begun, not yet done: Vietnam's remarkable progress on poverty reduction and the emerging challenges. Retrieved 6 February 2018 from http://www.ngocentre.org.vn/files/downloads/Jobs/About\%20Us/Resources/ Conference/24_aug_2012_pa2_full_report_7172012.pdf

Wu, A. (2017). The signal effect of government R\&D subsidies in China: Do ownership matter? Technological Forecasting and Social Change, 117(C), 339-345.

Zhang, H., Li, L., Zhou, D., \& Zhou, P. (2014). Political connections, government subsidies and firm financial performance: Evidence from renewable energy manufacturing in China. Renewable Energy, 63, 330-336. https://doi.org/10.1016/j.renene. 2013.09.029

Zhou, Q., Faff, R., \& Alpert, K. (2014). Bias correction in the estimation of dynamic panel models in corporate finance. Journal of Corporate Finance, 25, 494-513. https://doi.org/10.1016/j.jcorpfin.2014.01.009 